\title{
Fractal Geometry Used for Evaluation of Corrosion Resistance of Fe-14Al-6Cr Wt. \% against Molten Glass
}

\author{
Adam Hotar ${ }^{1}$, Vlastimil Hotar ${ }^{2}$ \\ ${ }^{1}$ Department of Material Science, Technical University of Liberec, Studentska 2, 46117 Liberec, Czech Republic, E- \\ mail: adam.hotar@tul.cz \\ ${ }^{2}$ Departmet of Glass Producing Machines and Robotics, Technical University of Liberec, Studentska 2, 46117 Liberec, \\ Czech Republic, E-mail: vlastimil.hotar@tul.cz
}

Corrosive attack of metals and alloys by molten glass can be described by parameters of surface roughness. Fractal geometry and statistic tools were used for surface roughness quantification. The obtained parameters of fractal geometry and statistics were determined on boundary curves between alloys and glass which had been generated from the digital photography of sample cross-section. This methodology was successfully used for quantification of surface changes of iron aluminides $\mathrm{Fe}-14 \mathrm{Al}-6 \mathrm{Cr}$ and austenitic steel during corrosion test in molten soda-lime glass at $1200^{\circ} \mathrm{C}$.

Keywords: Fractal geometry, corrosion, molten soda-lime glass, iron aluminide, austenitic steel

\section{Acknowledgement}

This research was supported by The Czech Science Foundation GACR (P108/12/1452).

\section{References}

[1] MANDELBROT, B.B. (1982). The fractal geometry of nature, second ed., Freeman WH and Co., New York.

[2] PEITGEN, H. O., JUERGENS, H., SAUPE, D. (1992). Chaos and Fractals: New Frontiers of Science. SpringerVerlag, New York, Berlin, Heidelberg

[3] EVERTSZ, C. J. G., PEITGEN, H. O., VOSS, R. F. (1996). Fractal Geometry and Analysis. World Scientific Publishing Co.Pte. Ltd. Singapore

[4] HILBORN, R. C. (2003). Chaos and Nonlinear Dynamics. New York: Oxford.

[5] GULICK, D. (1992). Encounters with Chaos. McGraw-Hill, Inc.

[6] LEVY, V.J., LUTTON, E., TRICOT, C. (1997). Fractals in Engineering. Springer-Verlag, New York, Berlin, Heidelberg

[7] CONCI, A., PROENCA, C.B. (1998). A fractal image analysis system for fabric inspection based on a box-counting method. In: Computer Networks and Isdn Systems, Vol. 30, pp. 1887-1895.

[8] YU, L., QI, D.W. (2011). Applying multifractal spectrum combined with fractal discrete Brownian motion model to wood defects recognition. In: Wood Science and Technology, Vol. 45, pp. 511-519.

[9] MUGUTHU, J.N., GAO, D. (2013). Profile Fractal Dimension and Dimensional Accuracy Analysis in Machining Metal Matrix Composites (MMCs). In: Materials and Manufacturing Processes, Vol. 28, pp. 1102-1109.

[10] ZHENG, C.X., SUN, D.W., AND ZHENG, L.Y. (2006). Recent applications of image texture for evaluation of food qualities - a review. In: Trends in Food Science \& Technology, Vol. 17, pp. 113-128.

[11] HOTAR, V. (2013). Fractal geometry for industrial data evaluation. In: Computers \& Mathematics with Applications, Vol. 66, pp. 113-121.

[12] HOTAR, V., NOVOTNY, F., AND REINISCHOVA, H. (2011). Objective evaluation of the corrugation test for sheet glass surfaces. In: Glass Technology-European Journal of Glass Science and Technology Part A, Vol. 52, pp. 197-202.

[13] HOTAR̆, V., NOVOTNÝ, F. (2005). Surface Profile Evaluation by Fractal Dimension and Statistic Tools. In proceedings: $11^{\text {th }}$ International Conference on Fracture. CCI Centro Congressi Internazionale s.r.l., pp. 588, Turin.

[14] HOTAR, V., NOVOTNY, F. (2004). Evaluation of surface defects by fractal geometry and statistical analysis. In: Glass Science and Technology, Vol. 77, pp. 230-237.

[15] HOTǍ̌, V., SALAČ, P. (2014) Surface Evaluation by Estimation of Fractal Dimension and Statistical Tools. The Scientific World Journal, vol. 2014, Article ID 435935, 10 pages. 
[16] HOTAR, A., KRATOCHVIL, P., AND HOTAR, V. (2009). The corrosion resistance of Fe 3 Al-based iron aluminides in molten glasses. In Kovove Materialy-Metallic Materials, Vol. 47, pp. 247-252.

[17] HOTAR, A., HOTAR, V., AND NOVOTNY, F. (2014). Corrosion behaviour of Fe-40Al-Zr (at.\%) alloy in molten soda-lime glass. In: Kovove Materialy-Metallic Materials, Vol: 52, pp. 149-155.

[18] DEEVI, S.C., SIKKA, V.K. (1996). Nickel and iron aluminides: an overview on properties, processing, and applications. In Intermetallics, Vol: 4, pp. 357-375

[19] ŠVEC, M., VODIČKOVÁ, V. (2014). The Effect of Niobium Addition and Heat Treatment on the Phase Structure of $\mathrm{Fe}_{3} \mathrm{Al}$ - Type Intermetallic Alloys. In Manufacturing Technology, Vol. 14, pp.456 - 461.

[20] ISO 4287 (1997). Geometrical Product Specifications (GPS) - Surface texture: Profile method - Terms, definitions and surface texture parameters. International Organization for Standardization, Geneva. 